\title{
PROGRESSIVE ALTERATIONS IN MINERAL PROFILING OF CITRUS INFECTED WITH CANKER CAUSED BY XANTHOMONAS AXONOPODIS PV. CITRI (HASSE)
}

\author{
HAMEED, A. ${ }^{1,4}-$ ATIQ, M. ${ }^{1 *}-$ JAVED, N. ${ }^{1}-$ AHMAD, A. ${ }^{2,4}-$ AHMED, Z.${ }^{3,4}$ \\ ${ }^{I}$ Department of Plant Pathology, University of Agriculture, Faisalabad, Pakistan \\ ${ }^{2}$ Department of Agronomy, University of Agriculture, Faisalabad, Pakistan \\ ${ }^{3}$ Department of Plant Breeding \& Genetics, University of Agriculture, Faisalabad, Pakistan \\ ${ }^{4}$ Center for advanced studies in Agriculture and Food Security (CAS), University of Agriculture \\ Faisalabad, Pakistan \\ *Corresponding author \\ e-mail: dratiq1@yahoo.com; phone: +92-333-4396-981
}

(Received 10 $0^{\text {th }}$ Apr 2019; accepted 12 $2^{\text {th }}$ Jul 2019)

\begin{abstract}
Mineral nutrients are important factors in plant-disease interactions. Experiments were conducted under Completely Randomized Block Design (CRD) with three replications to find out the alterations in mineral status of citrus leaves infected with the canker. Leaves of susceptible (Grapefruit, Succari, Kinnow) and resistant (Kumquat, Jaffa, China lemon) varieties of inoculated and un-inoculated citrus plant leaves from 6 varieties were collected and analyzed by using Nested Structured Design to check the ionic status of nutrients and minerals. Variations $(p \leq 5)$ were observed in the mineral status among the treatment groups (Un-inoculated and inoculated), types (susceptible and resistant) and in the citrus varieties in response of citrus canker infection. Resistant type of plants expressed 6.88, 1.39, 8.33, $2.19,1.84,1.46,1.56,2.82$ and 1.89 while susceptible type expressed $5.39,1.13,5.90,1.89,1.44,1.11$, $1.03,1.81$ and 0.92 variations in concentration of $\mathrm{N}$ and $\mathrm{P}(\%)$ while $\mathrm{K}, \mathrm{Ca}, \mathrm{Mg}, \mathrm{Na}, \mathrm{Zn}, \mathrm{Fe}$ and $\mathrm{Cu}$ in $(\mathrm{ppm})$ respectively. Susceptible varieties accumulated lower concentrations as compared to resistant varieties which have an increased level of minerals. Plants become more prone to pathogen infection due to the deficiency of these nutrients which help the plants in restricting the pathogens.
\end{abstract}

Keywords: citrus canker, mineral nutrients, plant-disease interaction, CRD, nested structured design

\section{Introduction}

Citrus is the most important cash and fruit crop grown all over the world. It grows best under tropical and subtropical ecological conditions (Jagtap et al., 2012; Wali et al., 2013). Worldwide, its total production estimated at 115 Million Metric Tons (MMT) while in case of Pakistan, it was 3.6 MMT (Memon, 2017). Citrus has much supplementary usage in various kinds of food and beverages having traditionally medicinal values (Gurib, 2006). Citrus is valuable due to its rich nutritional grade and is more precious because of its highly dietary status. It has large amount of sugars, amino acids, organic acids, vitamins, antioxidants like flavonoides, terpenes, macro and micronutrients minerals (calcium, magnesium) along with rich source of vitamin C (Ladaniya et al., 2010). In Pakistan, citrus area is 20.7 million hectares with 36 million tons production (Memon, 2017). Pakistan earned 17.78 billion Pakistani rupees (PKR) by exporting 3.8 million tonns kinnow during the year of 2017 (Memon, 2017). Citrus is spoiled by nearly one hundred and fifty pathogens and disorders caused by fungal, viral and bacterial diseases like canker, greening (HLB), scab, gummosis, whithertip, greecy spot, black spot, decline and citrus tristeza virus 
which results in severe losses but canker caused by Xanthomonas axonopodis pv. citri (Xac) is one of the major threat among all the constraints faced by the citrus crop in Pakistan (Ware, 2015). Pakistan which is one of the major exporters of citrus in the world, facing a huge economic losses due to this disease. During 2015-16, 144 consignments of citrus were rejected by the European Union due to the infection of Xac (Pervaiz, 2015). Overall, the yield losses due to canker is increasing day by day (Sahi et al., 2007).

Bacteria gain entry in to the leaves through stomata, wounds/injuries and penetrate into the intercellular spaces of leaves and attaches to the mesophyll cells using type III secretary system and releases effecter proteins (toxins) which causes hypertrophy, hyperplasia and and causes multiple infection and produces water soaked lesion with yellow hollow. Epidermis gets raised and began to rupture. After two weeks of infection, the watery lesions began to dry and form necrotic lesions. Copper-based chemicals are used in conventional management of canker. No doubt, these chemicals expressed quick response against canker but are not eco-friendly and have ill effects on human health. So, there is dire need to develop an alternate strategy which should be cost effective with least residual effects and is eco-friendly (Kumar et al., 2011). Xac forms a bio film on leaf surface and gains entry in to leaves via natural leaf openings or the wounds. Upon bacterial invasion the defense mechanism of plant which is composed of a series of well coordinated molecular networks is triggered, various transcriptomic reprogramming events, ultra-structural reinforcements and physiological changes takes place in a series of defense related events. The first line of plant's defence involves production of reactive oxygen species (ROS) as a part of PAMPTriggered immunity (PTI). The second line of defense is triggered when certain pathogen effecter molecules are recognized by the $\mathrm{R}$ gene products which results in multiple responses including HR response and programmed cell death for pathogen confinement and preventing disease spread (Roeschlin et al., 2017).

Mineral nutrients are essential not only for plant growth and development but also play an important role in plant-disease interaction as well as in reducing disease to a tolerable level (Bradbury, 2016). Nutrients are not responsible for disease severity and resistance but they also take part in the disease development by fluctuating the functioning of the plants or the expansion of disease (Arshadi et al., 2013). Sometime, these nutrients may increase the plant growth which ultimately effects the pathogenic infection and their deficiency also takes the plant towards susceptibility against the pathogen (Bruning and Gabriel, 2003). In the same way these nutrients influence the disease susceptibility by inducing the chemical alterations in the host plant (Mubeen et al., 2015). When a pathogen attacks, it affects the physiology of plant and reduced nutrient uptake, assimilation, absorption, mobility and their consumption. In diseased tissues, translocation or consumption of nutrients are influenced by pathogens, result in nutrient deficiencies. These nutrients have a sound effect on all the key components which play role in the disease severity. Besides, plants have more chances of damage by pathogens that suffer with low level of nutrients which are necessary for building cell walls and other structural tissues (Ryan et al., 2011). In most of the bacterial diseases of plants, pathogen enter and multiply in to the host through the xylum vessels which is the main system for transportation of water and nutrients from the roots to the leaves (Honger et al., 2016). The presence of these pathogenic bacteria produce ooze and slime within the vessels which causing blockage of nutrients, produce rough water soaked lesions on the leaves and after on surface of fruits. Some plant nutrients play a vital role in reducing the capability of bacteria to produce vessels blocking slime (Spann and Schumann, 2010). In sustainable agriculture, management of nutrients has received little attention for control of disease. The physiological functions of plant nutrients are generally well 
understood but still there is a little knowledge regarding the relationship between plantpathogens and nutrients. It is reported that fundamental essential macro and micro nutrients for healthy citrus plants are N, P, K, Mg, Fe, Ca, S, Zn, Cu and B (Zekri and Obreza, 2015). Pathogen uses these nutrients in their growth and development, reduced their accessibility to the host plants and enhancing susceptibility of plant towards various infections (Sahi et al., 2010). Enhancement of plant health is an effective way of combating citrus canker. When bacteria attack on citrus plant, it induces different changes in its metabolism. It interferes with its defense mechanism by disturbing its ionic content which ultimately leads to disease development. A method for the enrichment of plant health and strengthening its defense mechanism against the pathogen attack is to analyze the mineral profile of healthy and diseased plants. The present study was designed to find out the biochemical alterations happened after the disease attack in citrus plants to pave the way towards successful management of citrus canker. For this purpose, mineral profiling of inoculated and uninoculated plants of susceptible and resistant citrus varieties was conducted.

\section{Materials and methods}

One year old seedlings of six varieties (Grape fruit, Succari, Kinnow, Kumquat, Jaffa and China lemon) were collected from the research area Institute of Horticultural Science, University of Agriculture Faisalabad (UAF). All varieties were sown in three replications in pots $(30 \times 15 \mathrm{~cm})$ containing field soil (sandy clay) previously sterilized by drenching $1 \%$ solution of formaline using a Completely Randomized Block Design (CRD) in the green house, research area of Department of Plant Pathology UAF. All the recommended horticultural practices were exercised including the doses of fertilizers and number of irrigations to keep the plants in healthy condition. Soil health analysis was also done to fulfill all requirements of minerals. A standard soil mix (2:1 clay and sand) was used in all experiments. The soil mixture tested $73 \mathrm{lb}$./acre phosphorus, $242 \mathrm{lb}$./acre exchangeable potassium. It was partially sterilized by (i) autoclaving for $2 \mathrm{~h}$ at $121{ }^{\circ} \mathrm{C}$ and $15 \mathrm{psi}$ (ii) fumigating in a sealed plastic container in which $1 \%$ formalin solution injected. The soil mixtures were aerated for seven days after treatment. Leaves showed characteristics symptoms of canker were collected in brown paper bags $(10$ " $\times$ 12") from research area of Institute of Horticultural Sciences and brought to the citrus pathology lab to isolate Xac by using streaking method. Nutrient Agar (NA) media (Beef extract $3 \mathrm{~g}$, Peptone $5 \mathrm{~g}$, Glucose $2.5 \mathrm{~g}$ and Agar $15 \mathrm{~g}, 1000 \mathrm{ml}$ distilled water for $1 \mathrm{~L}$ media) was used to isolate $\mathrm{Xac}$. For the preparation of inoculums for pathogencity, bacterial culture was grown overnight in $10 \mathrm{ml}$ nutrient broth at $25^{\circ} \mathrm{C}$ and put on shaker (RTSK-0300, Robus United Kingdom) at $200 \mathrm{rpm}$. Inoculum was measured equivalent to $10^{8}$ colony-forming units $(c f u)$ per $\mathrm{ml}$ with the help of spectrophotometer (Hitachi U2001, model 121-003) (Francis et al., 2010). Inoculation was done at morning in the green house by using syringe method (using a $1 \mathrm{~cm}^{3}$ needleless tuberculin syringe). Bacterial suspension (approximately $2 \mu \mathrm{l}$ ) was infiltrated into the leaf until the watersoaked area reached about $6 \mathrm{~mm}$ in diameter. Three areas on each side of the leaf midvein were infiltrated. Disease incidence was confirmed via Koch's postulates (Juhasz et al., 2013). For mineral analysis, total 300 samples (150 inoculated \& 150 uninoculated), 50 ( 25 healthy $\& 25$ diseased) from each variety one time after inoculation were collected. Disease symptoms were appeared on the susceptible and resistant type of varieties after the inoculation (Fig. 1). 

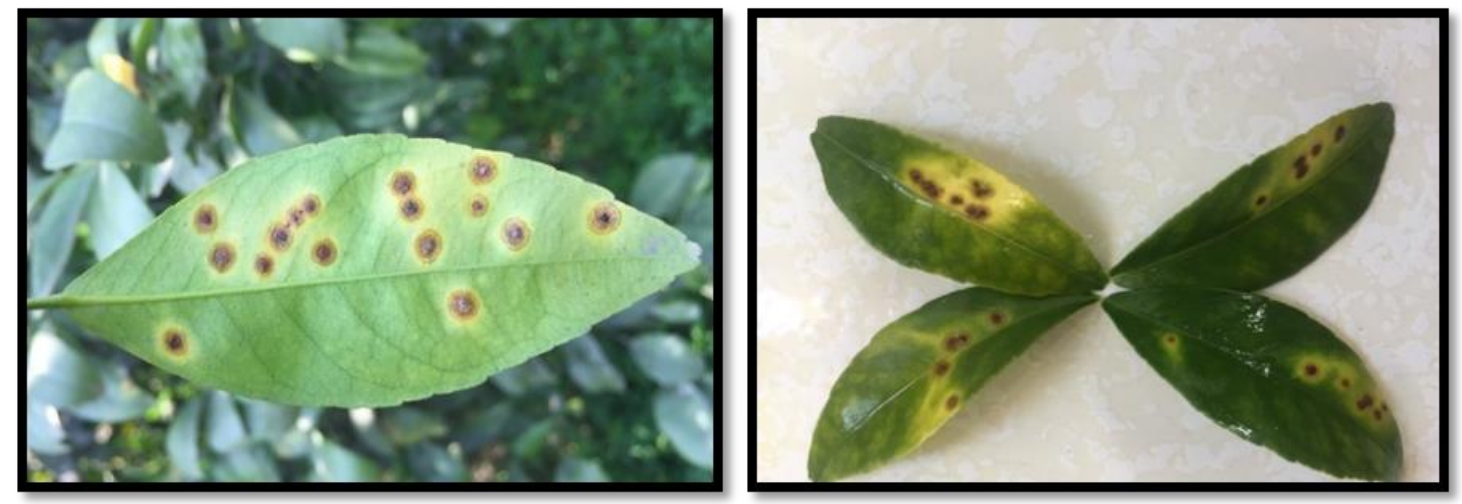

Figure 1. Disease symptoms after the inoculation of Xac on susceptible (left) and resistant (right) varieties

\section{Estimation of mineral gradient in citrus cultivar}

The leaves samples comprising of inoculated and un-inoculated groups both from resistant and susceptible reaction types were taken, stored in the refrigerator (Dawlance DW 550) and standard analytical method were employed for the determination of different biochemical compound via 'Nested Structured Design (Gomez and Gomez, 1984). Leaves were surface sterilized by using $0.2 \% \mathrm{NaOCl}$ solution to eliminate all debris, followed by washing with $0.8 \%$ HCL solution (to remove metallic contamination from them) and then with de-ionized water (to get rid of previous two solutions). After this, leaves were first air dried, later placed inside brown paper bags $(23 \times 15 \mathrm{~cm})$ and then subjected to oven (BST/HAO-1122) drying at $70{ }^{\circ} \mathrm{C}$ for 3 days ( $72 \mathrm{~h}$ approx.) to attain a constant weight. After drying the leaf samples were grind in to a fine powder by using sterilized mortar and pestle. After thoroughly grinding, samples $(100 \mathrm{mg})$ were boiled in $10 \mathrm{ml}$ of $1.4 \mathrm{M}$ nitric acid on a hotplate (TH-550; Advantec, Tokyo, Japan) at $100{ }^{\circ} \mathrm{C}$ for $25-30 \mathrm{~min}$. The solution was left for cooling, afterwards the sample suspension was diluted up to 250 time using distilled water and analysis for determining concentrations of key elements including; N, P, K, Zn, Mg, Ca, Fe and $\mathrm{Na}$ were done by following Bhargava and Raghupathi (1995) method. Potassium, Zinc, Magnesium, Calcium, Iron and Sodium contents were measured on ppm (parts per million) while Nitrogen and Phosphorus were recorded on percent basis.

\section{Estimation of phosphorus from citrus leaves}

Sample solution of $0.1 \mathrm{ml}$ was prepared by wet digestion method. Solution was taken in a volumetric flask (ASTM-E288) and $1 \mathrm{ml}$ of ammonium molybdate reagent $\left[\left(\mathrm{NH}_{4}\right)_{6} \mathrm{Mo}_{7} \mathrm{O}_{24} .4 \mathrm{H}_{2} \mathrm{O}\right]$ along with $8.6 \mathrm{ml}$ of distilled water was added. Amino nephtholsulphonic acid $\left(\mathrm{C}_{10} \mathrm{H}_{9} \mathrm{NO}_{4} \mathrm{~S}\right)$ was added after swirling the flask to mix solution. Sample solution placed at $720 \mathrm{~nm}$ on a spectrophotometer (Hitachi U-2001, model 121-003) and absorbency was measured by using distilled water as a reagent blank. Absorbency was compared to previously prepared standard curve (Bolts and Mellon, 1948; Fiske and Subbarow, 1925) by atomic absorption spectrometer (Hitachi polarized Zeeman) for determination of phosphorous concentration. 


\section{Determination of potassium and sodium from leaves of diseased and healthy citrus plants}

Determination of sodium and potassium contents was done by using Flame phorometer (PFP-7, Janway). Potassium chloride and sodium chloride were used as standards for the measurement of $\mathrm{K}$ and $\mathrm{Na}$ respectively. Four concentrations 10, 20, 30 and $40 \mathrm{ppm}$ for both potassium and sodium were used for preparing the standard curves. Fresh working standards were prepared immediately before use.

\section{Estimation of copper, magnesium, iron, calcium and zinc from citrus leaves}

Determination of Calcium $(\mathrm{Ca})$, Magnesium $(\mathrm{Mg})$, iron $(\mathrm{Fe})$, Copper $(\mathrm{Cu})$ and zinc (Zn) was done using a spectrophotometer (Hitachi U-2001, model 121-003). Standards that used for the estimation of these ions were Iron sulphate $\left(\mathrm{FeSO}_{4}\right)$, Magnesium sulphate $\left(\mathrm{MgSO}_{4}\right)$, Zinc oxide $(\mathrm{ZnO})$, Calcium chloride $\left(\mathrm{CaCl}_{2}\right)$ and Copper sulphate $\left(\mathrm{CuSO}_{4}\right)$. For obtaining standard curves, concentrations 10, 20, 40, 80 and $100 \mathrm{ppm}$ for $\mathrm{Ca} ; 2,2.5,3$, and $3.5 \mathrm{ppm}$ for $\mathrm{Cu} ; 5,10,15$ and $20 \mathrm{ppm}$ for $\mathrm{Mg} ; 0.2,0.3,0.5$ and $2 \mathrm{ppm}$ for zinc and 1, 2 and $3 \mathrm{ppm}$ for iron were used. Standard solutions were prepared just before this activity. Atomic absorption spectrophotometer (GA 3202 HGA) was used for the analysis of these minerals both from resistant and healthy cultivars of citrus.

\section{Estimation of total nitrogen from diseased and healthy citrus leaves}

Determination of total nitrogen from the sample was done by using Micro Kjeldahl method (46MC; Quickfit, England) (Kjeldahl, 1983). Proper amount of sample was oven-dried (D6450 Hanus; Heraeus) and taken in long neck Kjeldahl flask. Concentrated sulphuric acid of $25 \mathrm{ml}$ and five grams of digestion mixture containing $\mathrm{K}_{2} \mathrm{SO}_{4}$ and $\mathrm{CuSO}_{4}$ was added. For boiling of the sample, Digestion hood (KB8S Kjeldatherm) was used. Contents of flask were distilled by using distilled water in $250 \mathrm{ml}$ volumetric flask (ASTM-E288). $10 \mathrm{ml}$ of this solution was distilled in micro Kjeldhal distillation apparatus (VAP20, Garhardt) in the presence of $10 \mathrm{ml}$ of $40 \%$ sodium hydroxide $(\mathrm{NaOH})$ solution. Ammonia produce in this reaction which was collected in a beaker containing $10 \mathrm{ml}$ of $2 \%$ boric acid $\left(\mathrm{H}_{3} \mathrm{BO}_{3}\right)$ solution. Boric acid with two drops of methyl red was used as an indicator. The solution was titrated against standard $0.1 \mathrm{~N}$ sulphuric acid to light pink point. Equation 1 was used to calculate the percentage of nitrogen.

$$
\text { Nitrogen } \%=\frac{0.1 \mathrm{~N} \mathrm{H}_{2} \mathrm{SO}_{4} \times 0.0014 \times 250}{\text { WI } \times 100} \times 100
$$

Total percentage of crude protein present in sample was estimated using Equation 2.

$$
\text { Crude protein }=\text { Nitrogen } \% \times 6.25
$$

\section{Statistical analysis}

The plant samples (all varieties) were divided in 2 groups i.e. un-inoculated and inoculated. Further each group contained of 2 reaction types: i) resistant, ii) susceptible, three susceptible citrus varieties were used: Grapefruit, Succari and Kinnow and three resistant varieties Kumquat, Jaffa and China lemon. Leaves sample of un-inoculated and 
inoculated plants from resistant varieties with a disease incidence ranging from $0-5 \%$ and susceptible plants showing above $25 \%$ incidence were acquired from the research area Department of Plant pathology near Center of Advanced Studies (CAS) University of Agriculture Faisalabad during 2018. For estimation of mineral contents, standard analytical methods via Nested Structured Design (Gomez and Gomez, 1984) were used and data were statistically analyzed by using PROC MiXED procedure of the Statistical Analysis System (SAS, 2009).

\section{Results}

Determination of minerals contents of $\mathrm{N}, \mathrm{P}, \mathrm{K}, \mathrm{Na}, \mathrm{Zn}, \mathrm{Ca}, \mathrm{Mg}, \mathrm{Fe}$ and $\mathrm{Cu}$ from inoculated and un-inoculated citrus plant

Samples of un-inoculated and inoculated with $\mathrm{Xac}$ both from susceptible and resistant plants were addressed for the determination of $\mathrm{N}, \mathrm{P}, \mathrm{K}, \mathrm{Ca}, \mathrm{Mg}, \mathrm{Na}, \mathrm{Zn}, \mathrm{Fe}$ and $\mathrm{Cu}$. Inoculated and un-inoculated citrus varieties expressed significant variations (on an average $3.31 \%$ across inoculated plants) and (on an average $8.91 \%$ across un-inoculated plants) which point out that nitrogen contents were clearly affected by the attack of Xac. Resistant and susceptible type showed $6.88 \%$ and $5.39 \%$ variation at $\mathrm{p} \leq 0.05$ and "Type" Component expressed $92.41 \%$ total variance. Total nitrogen variability which variety exhibited was $0.83 \%$ (Table 1). Resistant cultivar "Kumquat" displayed maximum nitrogen amount at $7.23 \%$ and susceptible cultivar "Grape fruit" minimum at $5.20 \%$ (Table 2). In case of phosphorus, there was seen a significant variation between inoculated $(0.68 \%)$ and un-inoculated $(1.81 \%)$ cultivars during the infection. Resistant and susceptible varieties showed total variance of $93.00 \%$ with $1.39 \%$ and $1.13 \%$ on individual basis respectively at $p \leq 0.05$ while the variance between the varieties that observed was $1.40 \%$. Maximum and minimum concentrations of phosphorus were accounted by Jaffa (1.46\%) and China lemon (1.00\%) respectively (Tables 3 and 4). Total variability of potassium contents exhibited by the group was 11.09 and in case of type were $88.61 \%$ on canker infection (Table 5). Resistant and susceptible varieties showed significant variation averaging 8.33 and $5.90 \mathrm{ppm}$ respectively. Inoculated $(3.58 \mathrm{ppm})$ and un-inoculated $(10.65 \mathrm{ppm})$ citrus cultivars also expressed significant variation under Xac infection. Resistant cultivar named as kumquat displayed maximum potassium concentration $(8.60 \mathrm{ppm})$ while minimum concentration of potassium was expressed by Grape fruit (5.66 ppm) at $p \leq 0.05$ (Table 6).

Regarding the calcium concentration, statistically significant difference was attained by the group having total variance of $4.08 \%$ (on an average $1.36 \mathrm{ppm}$ in case of inoculated citrus plants and $2.11 \mathrm{ppm}$ for un-inoculated plants) as shown in Table 7. In the same way, resistant cultivars expressed 2.19 ppm while susceptible cultivars showed $1.89 \mathrm{ppm}$ variation as compared to the types which had $91.84 \%$ variability in the result of canker infection at $p \leq 0.05$. Significant variation was also expressed by the varieties with the amount of $1.46 \%$ of the total variance. Calcium concentrations of 2.26, 2.11, and $2.19 \mathrm{ppm}$ were showed by Kumquat, Jaffa, and China lemon (resistant types), while $1.75,1.86$, and $2.06 \mathrm{ppm}$ concentrations were shown by susceptible varieties Grape fruit, Succari, and Kinnow, respectively as given in Table 8. Magnesium articulated a total variability of $4.93 \%$ with a significant variation between the inoculated $(0.63 \mathrm{ppm})$ and un-inoculated $(2.65 \mathrm{ppm})$ under the disease conditions. On an average, $1.84 \mathrm{ppm}$ and $1.44 \mathrm{ppm}$ were observed in case resistant and susceptible citrus varieties respectively with a total variation of $93.27 \%$. Varieties showed a total variance of 
$0.72 \mathrm{ppm}$ for magnesium. Resistant variety Kumquat expressed maximum concentration of magnesium with $1.90 \mathrm{ppm}$ and susceptible variety Grape fruit showed minimum magnesium contents with amount of $1.19 \mathrm{ppm}$ (Tables 9 and 10).

In group, sodium concentration had significant variation in inoculated and uninoculated citrus varieties expressed (on average $0.62 \%$ across inoculated plants) and (on average 1.95\% across uninoculated plant) as given in Table 11 and significant variations $(92.19 \%)$ were attained by resistant and susceptible cultivar averaging $1.46 \mathrm{ppm}$ and $1.11 \mathrm{ppm}$ respectively. Kumquat with $1.60 \mathrm{ppm}$ and Grape fruit with 1.03 ppm expressed maximum and minimum sodium concentration (Table 12).

Table 1. Nested ANOVA of mineral concentrations of nitrogen in inoculated and uninoculated citrus plant leaves

\begin{tabular}{c|c|c|c|c|c|c|c}
\hline \multicolumn{1}{c}{ SOV } & DF & SS & MS & F value & Pr > F & $\begin{array}{c}\text { Variance } \\
\text { component }\end{array}$ & \% of total \\
\hline Type (A) & 1 & 845.712 & 845.712 & 27.457 & $0.035^{*}$ & 15.091 & 92.41 \\
Group (B) & 2 & 61.603 & 30.801 & 25.163 & $0.000^{*}$ & 1.095 & 6.71 \\
Variety (C) & 8 & 9.792 & 1.224 & 135.849 & $0.000^{*}$ & 0.135 & 0.83 \\
Error & 96 & 0.865 & 0.009 & - & - & 0.009 & 0.06 \\
Total & 107 & 917.973 & - & - & - & 16.330 & - \\
\hline
\end{tabular}

*Significant

Table 2. Amount of nitrogen in reaction groups (inoculated and un-inoculated), types (resistant and susceptible) and in varieties of citrus plant leaves

\begin{tabular}{|c|c|c|c|c|c|c|c|c|c|c|c|c|}
\hline \multicolumn{13}{|c|}{ Nitrogen $(\%)$} \\
\hline \multirow{3}{*}{$\begin{array}{c}\text { Varieties (C) } \\
\text { Type (A) } \\
\text { Group (B) }\end{array}$} & \multicolumn{2}{|c|}{ Kumquat } & \multicolumn{2}{|c|}{ Jaffa } & \multicolumn{2}{|c|}{ China Lemon } & \multicolumn{2}{|c|}{ Grape fruit } & \multicolumn{2}{|c|}{ Succari } & \multicolumn{2}{|c|}{ Kinnow } \\
\hline & \multicolumn{6}{|c|}{ Resistant } & \multicolumn{6}{|c|}{ Susceptible } \\
\hline & Inoc. & Uninoc. & Inoc. & Uninoc. & Inoc. & Uninoc. & Inoc. & Uninoc. & Inoc. & Uninoc. & Inoc. & Uninoc. \\
\hline $\begin{array}{l}\text { Amount of } \mathrm{N} \\
\text { in }(\mathrm{C})\end{array}$ & 4.12 & 10.3 & 3.63 & 9.36 & 3.96 & 9.85 & 2.46 & 7.96 & 2.80 & 8.15 & 3.16 & 7.80 \\
\hline $\begin{array}{l}\text { Av. amount } \\
\text { of } N \text { in }(C)\end{array}$ & \multicolumn{2}{|c|}{7.23} & \multicolumn{2}{|c|}{6.49} & \multicolumn{2}{|c|}{6.91} & \multicolumn{2}{|c|}{5.20} & \multicolumn{2}{|c|}{5.47} & \multicolumn{2}{|c|}{5.48} \\
\hline $\begin{array}{l}\text { Av. amount } \\
\text { of } N \text { in }(A)\end{array}$ & \multicolumn{12}{|c|}{ Resistant $=6.88$ Susceptible $=5.39$} \\
\hline $\begin{array}{l}\text { Av. amount } \\
\text { of } N \text { in }(B)\end{array}$ & \multicolumn{12}{|c|}{ Un-inoculated $=8.91$ Inoculated $=3.31$} \\
\hline
\end{tabular}

Table 3. Nested ANOVA of mineral concentrations of phosphorus in inoculated and uninoculated citrus plant leaves

\begin{tabular}{c|c|c|c|c|c|c|c}
\hline \multicolumn{1}{c}{ Phosphorus (\%) } \\
\hline SOV & DF & SS & MS & F value & Pr > F & $\begin{array}{c}\text { Variance } \\
\text { component }\end{array}$ & \% of total \\
\hline Type (A) & 1 & 34.566 & 34.566 & 32.205 & $0.030^{*}$ & 0.620 & 93.00 \\
Group (B) & 2 & 2.146 & 1.073 & 12.668 & $0.003 *$ & 0.037 & 5.49 \\
Variety (C) & 8 & 0.677 & 0.084 & 111.594 & $0.000^{*}$ & 0.009 & 1.40 \\
Error & 96 & 0.072 & 0.000 & - & - & 0.001 & 0.11 \\
Total & 107 & 37.464 & & - & - & 0.667 & - \\
\hline
\end{tabular}

*Significant 
Hameed et al.: Progressive alterations in mineral profiling of citrus infected with canker caused by Xanthomonas axonopodis pv. citri (Hasse)

-13632 -

Table 4. Amount of phosphorus in reaction groups (inoculated and un-inoculated), types (resistant and susceptible) and in varieties of citrus plant leaves

\begin{tabular}{|c|c|c|c|c|c|c|c|c|c|c|c|c|}
\hline \multicolumn{13}{|c|}{ Phosphorus (\%) } \\
\hline \multirow{2}{*}{$\begin{array}{c}\text { Varieties }(\mathbf{C}) \\
\text { Type (A) }\end{array}$} & \multicolumn{2}{|c|}{ Kumquat } & \multicolumn{2}{|c|}{ Jaffa } & \multicolumn{2}{|c|}{ China Lemon } & \multicolumn{2}{|c|}{ Grape fruit } & \multicolumn{2}{|c|}{ Succari } & \multicolumn{2}{|c|}{ Kinnow } \\
\hline & \multicolumn{6}{|c|}{ Resistant } & \multicolumn{6}{|c|}{ Susceptible } \\
\hline Group (B) & Inoc. & Uninoc. & Inoc. & Uninoc. & Inoc. & Uninoc. & Inoc. & Uninoc. & Inoc. & Uninoc. & Inoc. & Uninoc. \\
\hline $\begin{array}{c}\text { Amount of } N \\
\text { in (C) }\end{array}$ & 0.82 & 1.98 & 0.76 & 1.85 & 0.84 & 2.07 & 0.45 & 1.55 & 0.55 & 1.67 & 0.78 & 1.76 \\
\hline $\begin{array}{l}\text { Av. amount } \\
\text { of } N \text { in }(C)\end{array}$ & & .40 & & .30 & & 46 & & .00 & & .11 & & .27 \\
\hline $\begin{array}{l}\text { Av. amount } \\
\text { of } N \text { in }(A)\end{array}$ & \multicolumn{12}{|c|}{ Resistant $=1.39$ Susceptible $=1.13$} \\
\hline $\begin{array}{l}\text { Av. amount } \\
\text { of } N \text { in (B) }\end{array}$ & \multicolumn{12}{|c|}{ Un-inoculated $=1.81$ Inoculated $=0.68$} \\
\hline
\end{tabular}

Table 5. Nested ANOVA of mineral concentrations of potassium in inoculated and uninoculated citrus plant leaves

\begin{tabular}{c|c|c|c|c|c|c|c}
\hline \multicolumn{7}{c}{ Potassium (ppm) } \\
\hline SOV & DF & SS & MS & F value & Pr > F & $\begin{array}{c}\text { Variance } \\
\text { component }\end{array}$ & \% of total \\
\hline Type (A) & 1 & 1351.077 & 1351.077 & 16.834 & 0.055 & 23.534 & 88.61 \\
Group (B) & 2 & 160.513 & 80.256 & 113.793 & $0.000^{*}$ & 2.946 & 11.09 \\
Variety (C) & 8 & 5.642 & 0.705 & 600.956 & $0.000^{*}$ & 0.078 & 0.29 \\
Error & 96 & 0.1127 & 0.001 & - & - & 0.001 & 0.00 \\
Total & 107 & 1517.346 & - & - & - & 26.559 & - \\
\hline
\end{tabular}

*Significant

Table 6. Amount of potassium in reaction groups (inoculated and uninoculated), types (resistant and susceptible) and in varieties of citrus plant leaves

\begin{tabular}{|c|c|c|c|c|c|c|c|c|c|c|c|c|}
\hline \multicolumn{13}{|c|}{ Potassium (ppm) } \\
\hline \multirow{2}{*}{$\frac{\text { Varieties (C) }}{\text { Type (A) }}$} & \multicolumn{2}{|c|}{ Kumquat } & \multicolumn{2}{|c|}{ Jaffa } & \multicolumn{2}{|c|}{ China Lemon } & \multicolumn{2}{|c|}{ Grape fruit } & \multicolumn{2}{|c|}{ Succari } & \multicolumn{2}{|c|}{ Kinnow } \\
\hline & \multicolumn{6}{|c|}{ Resistant } & \multicolumn{6}{|c|}{ Susceptible } \\
\hline Group (B) & Inoc. & Uninoc. & Inoc. & Uninoc. & Inoc. & Uninoc. & Inoc. & Uninoc. & Inoc. & Uninoc. & Inoc. & Uninoc. \\
\hline $\begin{array}{l}\text { Amount of } \mathrm{N} \\
\text { in }(\mathrm{C})\end{array}$ & 5.08 & 12.12 & 4.34 & 11.71 & 4.77 & 11.97 & 2.25 & 9.07 & 2.68 & 9.11 & 2.36 & 9.40 \\
\hline $\begin{array}{l}\text { Av. amount } \\
\text { of } N \text { in }(C)\end{array}$ & & 60 & & .02 & & 3.37 & & 5.66 & & .16 & & .88 \\
\hline $\begin{array}{l}\text { Av. amount } \\
\text { of } N \text { in }(A)\end{array}$ & \multicolumn{12}{|c|}{ Resistant $=8.33$ Susceptible $=5.90$} \\
\hline $\begin{array}{l}\text { Av. amount } \\
\text { of } N \text { in }(B)\end{array}$ & \multicolumn{12}{|c|}{ Un-inoculated $=10.65$ Inoculated $=3.58$} \\
\hline
\end{tabular}


Table 7. Nested ANOVA of mineral concentrations of calcium in inoculated and uninoculated citrus plant leaves

\begin{tabular}{c|c|c|c|c|c|c|c}
\hline \multicolumn{7}{c}{ Calcium (ppm) } \\
\hline SOV & DF & SS & MS & F value & Pr > F & $\begin{array}{c}\text { Variance } \\
\text { component }\end{array}$ & \% of total \\
\hline Type (A) & 1 & 49.410 & 49.410 & 40.390 & $0.024^{*}$ & 0.892 & 91.84 \\
Group (B) & 2 & 2.446 & 1.223 & 8.002 & $0.012^{*}$ & 0.040 & 4.08 \\
Variety (C) & 8 & 1.223 & 0.152 & 6.011 & $0.000^{*}$ & 0.014 & 1.46 \\
Error & 96 & 2.441 & 0.025 & - & - & 0.025 & 2.62 \\
Total & 107 & 55.521 & - & - & - & 0.972 & - \\
\hline
\end{tabular}

*Significant

Table 8. Amount of calcium in reaction groups (inoculated and un-inoculated), types (resistant and susceptible) and in varieties of citrus plant leaves

\begin{tabular}{|c|c|c|c|c|c|c|c|c|c|c|c|c|}
\hline \multicolumn{13}{|c|}{ Calcium (ppm) } \\
\hline \multirow{2}{*}{$\frac{\text { Varieties }(\mathrm{C})}{\text { Type (A) }}$} & \multicolumn{2}{|c|}{ Kumquat } & \multicolumn{2}{|c|}{ Jaffa } & \multicolumn{2}{|c|}{ China Lemon } & \multicolumn{2}{|c|}{ Grape fruit } & \multicolumn{2}{|c|}{ Succari } & \multicolumn{2}{|c|}{ Kinnow } \\
\hline & \multicolumn{6}{|c|}{ Resistant } & \multicolumn{6}{|c|}{ Susceptible } \\
\hline Group (B) & Inoc. & Uninoc. & Inoc. & Uninoc. & Inoc. & Uninoc. & Inoc. & Uninoc. & Inoc. & Uninoc. & Inoc. & Uninoc. \\
\hline $\begin{array}{l}\text { Amount of } N \\
\text { in }(C)\end{array}$ & 1.59 & 2.94 & 1.39 & 2.83 & 1.49 & 2.88 & 1.05 & 2.44 & 1.17 & 2.55 & 1.47 & 2.65 \\
\hline $\begin{array}{l}\text { Av. amount } \\
\text { of } N \text { in }(C)\end{array}$ & \multicolumn{2}{|c|}{2.26} & \multicolumn{2}{|c|}{2.11} & \multicolumn{2}{|c|}{2.19} & \multicolumn{2}{|c|}{1.75} & \multicolumn{2}{|c|}{1.86} & \multicolumn{2}{|c|}{2.06} \\
\hline $\begin{array}{l}\text { Av. amount } \\
\text { of } N \text { in }(A)\end{array}$ & \multicolumn{12}{|c|}{ Resistant $=2.19$ Susceptible $=1.89$} \\
\hline $\begin{array}{l}\text { Av. amount } \\
\text { of } N \text { in }(B)\end{array}$ & \multicolumn{12}{|c|}{ Un-inoculated $=2.11$ Inoculated $=1.36$} \\
\hline
\end{tabular}

Table 9. Nested ANOVA of mineral concentrations of magnesium in inoculated and uninoculated citrus plant leaves

\begin{tabular}{c|c|c|c|c|c|c|c}
\hline \multicolumn{7}{c}{ Magnesium (ppm) } \\
\hline SOV & DF & SS & MS & F value & Pr > F & $\begin{array}{c}\text { Variance } \\
\text { component }\end{array}$ & \% of total \\
\hline Type (A) & 1 & 104.725 & 104.725 & 36.827 & $0.026^{*}$ & 1.887 & 93.27 \\
Group (B) & 2 & 5.687 & 2.843 & 18.499 & $0.001^{*}$ & 0.100 & 4.93 \\
Variety (C) & 8 & 1.229 & 0.153 & 7.065 & $0.000^{*}$ & 0.015 & 0.72 \\
Error & 96 & 2.088 & 0.021 & - & - & 0.022 & 1.08 \\
Total & 107 & 113.731 & - & - & - & 2.023 & - \\
\hline
\end{tabular}

$*$ = Significant 
Hameed et al.: Progressive alterations in mineral profiling of citrus infected with canker caused by Xanthomonas axonopodis pv. citri (Hasse)

-13634 -

Table 10. Amount of magnesium in reaction groups (inoculated and un-inoculated), types (resistant and susceptible) and in varieties of citrus plant leaves

\begin{tabular}{|c|c|c|c|c|c|c|c|c|c|c|c|c|}
\hline \multicolumn{13}{|c|}{ Magnesium (ppm) } \\
\hline \multirow{2}{*}{$\begin{array}{c}\text { Varieties (C) } \\
\text { Type (A) }\end{array}$} & \multicolumn{2}{|c|}{ Kumquat } & \multicolumn{2}{|c|}{ Jaffa } & \multicolumn{2}{|c|}{ China Lemon } & \multicolumn{2}{|c|}{ Grape fruit } & \multicolumn{2}{|c|}{ Succari } & \multicolumn{2}{|c|}{ Kinnow } \\
\hline & \multicolumn{6}{|c|}{ Resistant } & \multicolumn{6}{|c|}{ Susceptible } \\
\hline Group (B) & Inoc. & Uninoc. & Inoc. & Uninoc. & Inoc. & Uninoc. & Inoc. & Uninoc. & Inoc. & Uninoc. & Inoc. & Uninoc. \\
\hline $\begin{array}{l}\text { Amount of } \mathrm{N} \\
\text { in }(\mathrm{C})\end{array}$ & 0.74 & 3.06 & 0.65 & 2.93 & 0.83 & 2.82 & 0.45 & 2.13 & 0.56 & 2.33 & 0.70 & 2.47 \\
\hline $\begin{array}{l}\text { Av. amount } \\
\text { of } N \text { in }(C)\end{array}$ & & .90 & & .78 & & 82 & & 1.29 & & 1.45 & & 1.59 \\
\hline $\begin{array}{l}\text { Av. amount } \\
\text { of } N \text { in (A) }\end{array}$ & \multicolumn{12}{|c|}{ Resistant $=1.84$ Susceptible $=1.44$} \\
\hline $\begin{array}{l}\text { Av. amount } \\
\text { of } N \text { in }(B)\end{array}$ & \multicolumn{12}{|c|}{ Un-inoculated $=2.62$ Inoculated $=0.65$} \\
\hline
\end{tabular}

Table 11. Nested ANOVA of mineral concentrations of sodium in inoculated and uninoculated citrus plant leaves

\begin{tabular}{c|c|c|c|c|c|c|c}
\hline \multicolumn{1}{c}{ Sodium (ppm) } \\
\hline SOV & DF & SS & MS & F value & Pr > F & $\begin{array}{c}\text { Variance } \\
\text { component }\end{array}$ & \% of total \\
\hline Type (A) & 1 & 47.733 & 47.733 & 28.194 & $0.034^{*}$ & 0.853 & 92.19 \\
Group (B) & 2 & 3.386 & 1.693 & 13.945 & $0.002^{*}$ & 0.058 & 6.29 \\
Variety (C) & 8 & 0.971 & 0.121 & 193.395 & $0.000^{*}$ & 0.013 & 1.45 \\
Error & 96 & 0.060 & 0.000 & - & - & 0.001 & 0.07 \\
Total & 107 & 52.151 & - & - & - & 0.925 & - \\
\hline
\end{tabular}

*Significant

Table 12. Amount of sodium in reaction groups (inoculated and un-inoculated), types (resistant and susceptible) and in varieties of citrus plant leaves

\begin{tabular}{|c|c|c|c|c|c|c|c|c|c|c|c|c|}
\hline \multicolumn{13}{|c|}{ Sodium (ppm) } \\
\hline \multirow{2}{*}{$\frac{\text { Varieties (C) }}{\text { Type (A) }}$} & \multicolumn{2}{|c|}{ Kumquat } & \multicolumn{2}{|c|}{ Jaffa } & \multicolumn{2}{|c|}{ China Lemon } & \multicolumn{2}{|c|}{ Grape fruit } & \multicolumn{2}{|c|}{ Succari } & \multicolumn{2}{|c|}{ Kinnow } \\
\hline & \multicolumn{6}{|c|}{ Resistant } & \multicolumn{6}{|c|}{ Susceptible } \\
\hline Group (B) & Inoc. & Uninoc. & Inoc. & Uninoc. & Inoc. & Uninoc. & Inoc. & Uninoc. & Inoc. & Uninoc. & Inoc. & Uninoc. \\
\hline $\begin{array}{c}\text { Amount of } N \\
\text { in (C) }\end{array}$ & 0.95 & 2.25 & 0.63 & 2.05 & 0.72 & 2.16 & 0.44 & 1.64 & 0.55 & 1.85 & 0.44 & 1.75 \\
\hline $\begin{array}{l}\text { Av. amount } \\
\text { of } N \text { in }(C)\end{array}$ & & 1.60 & & .34 & & .44 & & 1.03 & & .20 & & .09 \\
\hline $\begin{array}{l}\text { Av. amount } \\
\text { of } N \text { in }(A)\end{array}$ & \multicolumn{12}{|c|}{ Resistant $=1.46$ Susceptible $=1.11$} \\
\hline $\begin{array}{l}\text { Av. amount } \\
\text { of } N \text { in }(B)\end{array}$ & \multicolumn{12}{|c|}{ Un-inoculated $=1.95$ Inoculated $=0.62$} \\
\hline
\end{tabular}


In case of zinc, significant variation was displayed by the inoculated and uninoculated citrus plants with the amount of $0.41 \mathrm{ppm}$ and $2.19 \mathrm{ppm}$ respectively (Table 13). Likewise, significant variation was also observed in resistant (1.56 ppm) and susceptible $(1.03 \mathrm{ppm})$ citrus plants with total variability of about 86.06 of zinc. Kumquat (1.68 ppm) showed maximum concentration of zinc while Grape fruit $(0.92 \mathrm{ppm})$ expressed minimum zinc concentration (Table 14). 15.82, 83.24 and $0.91 \%$ total variability was observed in groups, type and varieties respectively in case of iron contents under the disease stress conditions (Table 15). Minimum and maximum iron concentration was showed by Grape fruit $(1.60 \mathrm{ppm})$ and Jaffa $(2.65$ ppm) respectively (Table 16). Both inoculated (1.67 ppm) and un-inoculated (2.14 ppm) citrus plant leaves showed significant variation in cupper contents on pathogen infection. Resistant and susceptible plant also expressed significant variations of 1.89 and $0.92 \mathrm{ppm}$ respectively with $59.87 \%$ of the total variance. Varieties showed a total variance of $1.89 \mathrm{ppm}$ for copper. Kumquat (2.05 ppm) and Grape fruit (0.79 ppm) displayed their maximum and minimum concentration of copper contents after the attack of Xac. (Tables 17 and 18).

Table 13. Nested ANOVA of mineral concentrations of zinc in inoculated and un-inoculated citrus plant leaves

\begin{tabular}{c|c|c|c|c|c|c|c}
\hline \multicolumn{1}{c}{ Zinc (ppm) } \\
\hline SOV & DF & SS & MS & F value & Pr > F & $\begin{array}{c}\text { Variance } \\
\text { component }\end{array}$ & \% of total \\
\hline Type (A) & 1 & 84.388 & 84.388 & 14.277 & $0.043^{*}$ & 1.453 & 86.06 \\
Group (B) & 2 & 11.821 & 5.910 & 27.234 & $0.000^{*}$ & 0.211 & 12.49 \\
Variety (C) & 8 & 1.736 & 0.217 & 477.795 & $0.000^{*}$ & 0.024 & 1.43 \\
Error & 96 & 0.043 & 0.000 & - & - & 0.000 & 0.03 \\
Total & 107 & 97.989 & - & - & - & 1.689 & - \\
\hline
\end{tabular}

*Significant

Table 14. Amount of zinc in reaction groups (inoculated and un-inoculated), types (resistant and susceptible) and in varieties of citrus plant leaves

\begin{tabular}{|c|c|c|c|c|c|c|c|c|c|c|c|c|}
\hline \multicolumn{13}{|c|}{ Zinc (ppm) } \\
\hline \multirow{2}{*}{$\begin{array}{c}\text { Varieties (C) } \\
\text { Type (A) }\end{array}$} & \multicolumn{2}{|c|}{ Kumquat } & \multicolumn{2}{|c|}{ Jaffa } & \multicolumn{2}{|c|}{ China Lemon } & \multicolumn{2}{|c|}{ Grape fruit } & \multicolumn{2}{|c|}{ Succari } & \multicolumn{2}{|c|}{ Kinnow } \\
\hline & \multicolumn{6}{|c|}{ Resistant } & \multicolumn{6}{|c|}{ Susceptible } \\
\hline Group (B) & Inoc. & Uninoc. & Inoc. & Uninoc. & Inoc. & Uninoc. & Inoc. & Uninoc. & Inoc. & Uninoc. & Inoc. & Uninoc. \\
\hline $\begin{array}{l}\text { Amount of } N \\
\text { in }(C)\end{array}$ & 0.50 & 2.87 & 0.46 & 2.43 & 0.49 & 2.63 & 0.31 & 1.54 & 0.34 & 1.65 & 0.35 & 1.96 \\
\hline $\begin{array}{l}\text { Av. amount } \\
\text { of } \mathrm{N} \text { in }(\mathrm{C})\end{array}$ & & .68 & & .44 & & 56 & & .92 & & .99 & & .15 \\
\hline $\begin{array}{l}\text { Av. amount } \\
\text { of } \mathrm{N} \text { in (A) }\end{array}$ & \multicolumn{12}{|c|}{ Resistant $=1.56$ Susceptible $=1.03$} \\
\hline $\begin{array}{l}\text { Av. amount } \\
\text { of } N \text { in (B) }\end{array}$ & \multicolumn{12}{|c|}{ Un-inoculated $=2.19$ Inoculated $=0.41$} \\
\hline
\end{tabular}


Table 15. Nested ANOVA of mineral concentrations of iron in inoculated and un-inoculated citrus plant leaves

\begin{tabular}{c|c|c|c|c|c|c|c}
\hline \multicolumn{1}{c}{ Iron (ppm) } \\
\hline SOV & DF & SS & MS & F value & Pr > F & $\begin{array}{c}\text { Variance } \\
\text { component }\end{array}$ & \% of total \\
\hline Type (A) & 1 & 171.032 & 171.032 & 11.324 & $0.048^{*}$ & 2.888 & 83.24 \\
Group (B) & 2 & 30.208 & 15.104 & 52.905 & $0.000^{*}$ & 0.549 & 15.82 \\
Variety (C) & 8 & 2.284 & 0.285 & 325.848 & $0.000^{*}$ & 0.032 & 0.91 \\
Error & 96 & 0.084 & 0.000 & - & - & 0.001 & 0.03 \\
Total & 107 & 203.608 & - & - & - & 3.469 & - \\
\hline
\end{tabular}

*Significant

Table 16. Amount of Iron in reaction groups (inoculated and un-inoculated), types (resistant and susceptible) and in varieties of citrus plant leaves

\begin{tabular}{|c|c|c|c|c|c|c|c|c|c|c|c|c|}
\hline \multicolumn{13}{|c|}{ Iron (ppm) } \\
\hline \multirow{2}{*}{$\frac{\text { Varieties }(\mathrm{C})}{\text { Type (A) }}$} & \multicolumn{2}{|c|}{ Kumquat } & \multicolumn{2}{|c|}{ Jaffa } & \multicolumn{2}{|c|}{ China Lemon } & \multicolumn{2}{|c|}{ Grape fruit } & \multicolumn{2}{|c|}{ Succari } & \multicolumn{2}{|c|}{ Kinnow } \\
\hline & \multicolumn{6}{|c|}{ Resistant } & \multicolumn{6}{|c|}{ Susceptible } \\
\hline Group (B) & Inoc. & Uninoc. & Inoc. & Uninoc. & Inoc. & Uninoc. & Inoc. & Uninoc. & Inoc. & Uninoc. & Inoc. & Uninoc. \\
\hline $\begin{array}{l}\text { Amount of } N \\
\text { in }(C)\end{array}$ & 1.55 & 4.39 & 1.24 & 4.06 & 1.42 & 4.25 & 0.55 & 2.97 & 0.71 & 2.94 & 0.85 & 3.13 \\
\hline $\begin{array}{l}\text { Av. amount } \\
\text { of } N \text { in }(C)\end{array}$ & & .97 & & 2.65 & & 2.84 & & 1.60 & & 1.83 & & 1.99 \\
\hline $\begin{array}{l}\text { Av. amount } \\
\text { of } \mathrm{N} \text { in (A) }\end{array}$ & \multicolumn{12}{|c|}{ Resistant $=2.82$ Susceptible $=1.81$} \\
\hline $\begin{array}{l}\text { Av. amount } \\
\text { of N in (B) }\end{array}$ & \multicolumn{12}{|c|}{ Un-inoculated $=3.57$ Inoculated $=1.05$} \\
\hline
\end{tabular}

Table 17. Nested ANOVA of mineral concentrations of cupper in inoculated and uninoculated citrus plant leaves

\begin{tabular}{c|c|c|c|c|c|c|c}
\hline \multicolumn{7}{c}{ Cupper (ppm) } \\
\hline SOV & DF & SS & MS & F value & Pr > F & $\begin{array}{c}\text { Variance } \\
\text { component }\end{array}$ & \% of total \\
\hline Type (A) & 1 & 58.904 & 58.904 & 4.085 & $0.041^{*}$ & 0.824 & 59.87 \\
Group (B) & 2 & 28.840 & 14.420 & 61.560 & $0.000^{*}$ & 0.525 & 38.19 \\
Variety (C) & 8 & 1.874 & 0.234 & 292.980 & $0.000^{*}$ & 0.026 & 1.89 \\
Error & 96 & 0.076 & 0.000 & - & - & 0.001 & 0.06 \\
Total & 107 & 89.695 & - & - & - & 1.376 & - \\
\hline
\end{tabular}

*Significant 
Table 18. Amount of copper in reaction groups (inoculated and un-inoculated), types (resistant and susceptible) and in varieties of citrus plant leaves

\begin{tabular}{|c|c|c|c|c|c|c|c|c|c|c|c|c|}
\hline \multicolumn{13}{|c|}{ Copper (ppm) } \\
\hline \multirow{2}{*}{$\begin{array}{c}\text { Varieties (C) } \\
\text { Type (A) }\end{array}$} & \multicolumn{2}{|c|}{ Kumquat } & \multicolumn{2}{|c|}{ Jaffa } & \multicolumn{2}{|c|}{ China Lemon } & \multicolumn{2}{|c|}{ Grape fruit } & \multicolumn{2}{|c|}{ Succari } & \multicolumn{2}{|c|}{ Kinnow } \\
\hline & \multicolumn{6}{|c|}{ Resistant } & \multicolumn{6}{|c|}{ Susceptible } \\
\hline Group (B) & Inoc. & Uninoc. & Inoc. & Uninoc. & Inoc. & Uninoc. & Inoc. & Uninoc. & Inoc. & Uninoc. & Inoc. & Uninoc. \\
\hline $\begin{array}{c}\text { Amount of } \mathrm{N} \\
\text { in }(\mathrm{C})\end{array}$ & 1.09 & 3.01 & 0.86 & 2.54 & 1.01 & 2.85 & 0.25 & 1.34 & 0.36 & 1.46 & 0.42 & 1.66 \\
\hline $\begin{array}{l}\text { Av. amount } \\
\text { of } N \text { in }(C)\end{array}$ & \multicolumn{2}{|c|}{2.05} & \multicolumn{2}{|c|}{1.70} & \multicolumn{2}{|c|}{1.93} & \multicolumn{2}{|c|}{0.79} & \multicolumn{2}{|c|}{0.91} & \multicolumn{2}{|c|}{1.04} \\
\hline $\begin{array}{l}\text { Av. amount } \\
\text { of } N \text { in (A) }\end{array}$ & \multicolumn{12}{|c|}{ Resistant $=1.89$ Susceptible $=0.92$} \\
\hline $\begin{array}{l}\text { Av. amount } \\
\text { of } N \text { in }(B)\end{array}$ & \multicolumn{12}{|c|}{ Un-inoculated $=2.14$ Inoculated $=0.67$} \\
\hline
\end{tabular}

\section{Discussion}

Mineral nutrients have a crucial role to play in plant- disease interaction. Determination of the effects of nutrients on disease development is based upon some major factors like concentration and forms of elements, disease type and weather conditions. Disease severity can be reduced by the accurate provision of nutrients and by understanding the dynamics between the nutritional status of plants and pathogens (Vandermeer et al., 2010). Establishment of pathogen on host surface, rate of penetration and development of disease are depending upon histological or morphological attributes of plant which are influenced by nutritional status of plant. Different types of nutrients have a distinct impact on resistance/susceptibility of host and virulence of pathogens which lead towards various kinds of alterations and consequences in the form of stresses (Bhaduri et al., 2014). Plants need balanced and in time availability of all required nutrients for their growth and development. This plant are more resistant against the various types of biotic and abiotic stresses, protected from new pathogenic infections and also enables to restrict existing infection better than the plants received deficient from proper nutrients supply. In the present study, nutritional requirements like $\mathrm{N}, \mathrm{P}, \mathrm{K}, \mathrm{Ca}, \mathrm{Mg}, \mathrm{Zn}, \mathrm{Fe}, \mathrm{Cu}$ and $\mathrm{B}$ of citrus plant leaves for their growth and development was observed.

In plants, nitrogen is a major element for many compounds of great significance such as protein, coenzymes, amino acid, amides, nucleic acids, nucleotides, chlorophyll, cytosine and auxins (Lakitan, 2007). Nitrogen deficiency in plant happens due to the excessive runoff and leaching. Plants responded abruptly to the application of nitrogen because it required for normal growth and development (Spann and Schumann, 2010). Its deficiency produces many other symptoms while excess availability of nitrogen also favors some diseases in plants (Dordas, 2008). In present study, it was observed that inoculated citrus varieties contained less amount of nitrogen while un-inoculated and resistant cultivars have high nitrogen contents that were also witnessed by Zekri and Obreza (2015).

Plants get high energy compounds like phospholipids, nucleic acids, coenzymes NAD, NADP, ATP and several others by the utilization of phosphorus (Huber and Graham, 1999; Spann and Schumann, 2010). Better root development due to the phosphorus nutrition may survive plants from the attack of various pathogens (Huber, 2007). In the current study, there was a clear difference of phosphorus accumulation in inoculated and 
uninoculated plants of both resistant and susceptible varieties. Findings of this study associated with the conclusions of Amusa et al. (2005), who experienced variations in phosphorus concentration between inoculated and un-inoculated plant.

Potassium is essential in enzyme activation; many of these enzymes are involved in carbohydrate metabolism. It is also helpful in controlling different plant diseases and pests. In the cellular functions, potassium acts as a mobile regulator for several activities of enzymes which ultimately reduces overall severity of disease. Nitrogen balances with the potassium particularly affect plants susceptibility against the disease (Dordas, 2008). Further, potassium has a great influence on plant physiological functions like hardening of tissues, opening of stomata, rate of photosynthesis and infestation degree of intensity (Huber and Graham, 1999; Rice, 2007; Spann and Schumann, 2010). Disease susceptibility is also linked with the deficiency of potassium because it has major role in plant metabolism. Under its deficiency, the synthesis of starch, protein and cellulose is impaired. In current study, we found that un-inoculated and resistant citrus varieties contained more potassium concentration as compare to the inoculated and diseased varieties which is also confirmed by Olanya et al. (2000). Sodium is taken up by the plants in the form of $\mathrm{Na}^{+}$and great variations were observed in inoculated and un-inoculated citrus varieties during this study. Susceptible and infected citrus varieties accumulated less sodium concentration than resistant and un-infected varieties. Closely related findings were reported by Jadon and Shah (2012) which verify the findings of ongoing study.

Calcium is absorbed by the plant in the form of $\mathrm{Ca}^{+}$cation and specifically used in growth of roots and leaves, microbial activities and in the uptake of other essential nutrients. It also helps in defense of plants against the penetration of pathogen and disease resistance. Calcium being a structural and functional component of plant cell wall and membrane acts as a secondary messenger within the symplast in signaling pathways (Rice, 2007). It also plays a key role in maintaining cell integrity and permeability because it is a main part of middle lamella in the form of calcium pectate (Spann and Schumann, 2010). Reduction in the concentration of calcium in plants leads towards the susceptibility against the disease. Calcium also act as a barrier in the regulation of sugars and amino acid molecules in between the cells (from the cytoplasm to the apoplast), which stimulate in the case of calcium reduction and increase the chance of pathogen infection (Marschner, 1995). In current studies, a reduction in calcium concentrations inside infected leaves of citrus plant were observed which was further confirmed and supported by the findings of Amusa et al. (2005).

Magnesium takes part in chlorophyll synthesis, in photosynthesis as central atom for chlorophyll and in carbohydrates metabolism (Devlin and Witham, 1983; Spann and Schumann, 2010). Since Mg is a vital element of structural tissues and take part in different physiological and biochemical processes. It is necessary for integrity and safeguarding of ribosomes and is associated with growth factors, mitosis, protein level, carbohydrates metabolism and oxidative phosphorylation. It also takes part in respiration, DNA and RNA synthesis, energy transfer reactions and also acts as a co-factor for many enzymes (Marschner, 2011). In current study an increase in magnesium contents was observed in resistant and un-inoculated citrus plants as compare to the susceptible and inoculated varieties which showed a significant reduction in Mg contents due to the attack of pathogen and these results are in accordance with the conclusions of Jadon and Shah (2012).

Zinc is important for plants due to its role in resistance to various plant diseases. It acts as a co-factor for various enzymes but the actual role in disease resistance is unclear (Rice, 2007). Application of zinc to the soils reduced the attack of root pathogens 
especially in vegetable crops (Kalim et al., 2003). It plays a significant role in starch and protein formation. A considerable variation in zinc concentration was observed in citrus varieties where there was a less concentration of zinc in inoculated and susceptible varieties as compare to un-inoculated and resistant varieties. Results of present study is supported by the work of Marschner (1995) and Dordas (2008) who also reported decrease in concentration of $\mathrm{Zn}$ due to disease.

Fe has a significant and lethal effect on the plant pathogens and its deficiency reduced the xylem lignifications (Evans et al., 2007). A clear variation was observed in the case of iron contents where leaves of un-inoculated and resistant citrus cultivars expressed high amount of $\mathrm{Fe}$ contents as compare to inoculated and susceptible one on the infection as witnessed by Zekri and Obreza (2003). It may due to the effect that plant pathogens generally have higher requirement of $\mathrm{Fe}$ and act as a virulence factor during the course of disease. The only justification may be the association of iron as a component of various flavoproteins (Metalloflavoproteins) which take part in biological oxidation and increase as a result of inoculation with the pathogen. Iron is found in iron-prophyrn proteins, which include cytochromes, peroxidases and catalases (these proteins may be responsible for increased catabolic activities in susceptible plants) and also act as a co-factor in reductionoxidation reactions (Devlin and Witham, 1983). Copper is an important component of lignin and have a key role in protein and carbohydrate metabolism and acts as catalyst in different metabolic activities of the plant (Imran and Gurmani, 2011). In current study, reduction in copper contents was observed on the attack of Xac. It was confirmed from this study that there is a relationship between nutrients and disease occurrence because pathogen wants nutrients for their growth. Same results of relationship between nutrients and disease severity were reported by Zekri and Obreza (2015).

\section{Conclusion}

Reduction in concentrations of minerals like nitrogen, phosphorus, potassium, calcium, magnesium, zinc, sodium, and copper in the diseased host plants were due to the utilization of minerals by the pathogen for its growth and survival. Timely provision of these macro and micro nutrients to plants is helpful in fortification of physical and biochemical processes of citrus plants and also in enhancing the resistance of plants against the canker.

Acknowledgements. Authors are highly thankful to the Higher Education Commission of Pakistan (NRPU-6373) for funding this study.

\section{REFERENCES}

[1] Amusa, N., Ashaye, O., Oladapo, M., Oni, M. (2005): Guava fruit anthracnose and the effects on its nutritional and market values in Ibadan, Nigeria. - World Journal Agricultural Sciences 1: 169-172.

[2] Arshadi, F., Sijam, K., Awang, Y. B. (2013): Genetic diversity of Xanthomonas axonopodis subsp. citri, causal agent of citrus canker. - Journal of Plant Protection Research 53: 312-316.

[3] Bhaduri, D., Rakshit, R., Chakraborty, K. (2014): Primary and secondary nutrients-a boon to defense system against plant diseases. - International Journal of Bio-resource and Stress Management 5: 461-466. 
[4] Bhargava, B. S., Raghupathi, H. B. (1995): Analysis of Plant Materials for Macro and Micro Nutrients. - In: Tandon, H. L. S. (eds.) Methods of Analysis of Soils, Plants, Waters and Fertilizers. Fertilizer Development and Consultation Organisation, New Delhi, pp. 61-62.

[5] Bolts, D. F., Mellon, M. G. (1948): Spectrophotometric determination of phosphorus as molybdi-phosphoric acid. - Analytical Chemistry 27: 749.

[6] Bradbury, K. (2016): An introduction to citrus fruit. - Pakistan journal of Plant Pathology 5(1): 52-60.

[7] Brunings, A. M., Gabriel, D. W. (2003): Xanthomonas citri: breaking the surface. Molecular Plant Pathology 4: 141-157.

[8] Devlin, R. M., Witham, F. H. (1983): Plant Physiology. - Wardsworth Pub. Co., Belmont, CA.

[9] Dordas, C. (2008): Role of nutrients in controlling plant diseases in sustainable agriculture. A review. - Agronomy for Sustainable Development 28: 33-46.

[10] Evans, I., Solberg, E., Huber. D. M. (2007): Copper and Plant Disease. - In: Datnoff, L. E. et al. (eds.) Mineral Nutrition and Plant Disease. American Phytopathological Society, St. Paul, MN, pp. 177-188.

[11] Fiske, C. A., Subbarow. I. (1925): The colorimetric determination of phosphorus. Journal of Biological Chemistry 66: 375.

[12] Francis, M. I., Peña, A., Graham, J. H. (2010): Detached leaf inoculation of germplasm for rapid screening of resistance to citrus canker and citrus bacterial spot. - European Journal of Plant Pathology 127: 571-578.

[13] Gomez, A. A., Gomez, K. A. (1984): Statistical Procedures for Agricultural Research. John Wiley and Sons, New York.

[14] Gurib-Fakim, A. (2006): Medicinal plants: traditions of yesterday and drugs of tomorrow. - Molecular Aspects of Medicine 27: 1-93.

[15] Honger, J., Essuman, E., Cornelius, E. (2016): The incidence, severity and aetiology of a bacterial canker disease of citrus in Ghana. - West African Journal of Applied Ecology 24: 31-44.

[16] Huber, D. M. (2007): Nitrogen and Plant Disease. - In: Datnoff, L. E. et al. (eds.) Mineral Nutrition and Plant Disease. American Phytopathological Society, St. Paul, MN, pp. 3144.

[17] Huber, D. M., Graham, R. D. (1999): The role of nutrition in crop resistance. Mineral nutrition of crops. - Fundamental Mechanisms and Implications 18: 169.

[18] Imran, M., Gurmani, Z. A. (2011): Role of macro and micro nutrients in the plant growth and development. - Science, Technology and Development 30(3): 36-40.

[19] Jadon, K., Shah, R (2012): Effect of Drechslera bicolor infection on physiology of bell pepper. - Journal of Plant Pathology \& Microbiology 3: 126.

[20] Jagtap, G. P., Thosar, R. U., Dey, U. (2012): Evaluation of plant extracts and bioagents for the control of gummosis of mandarin orange (Citrus reticulata blanko) caused by Phytophthora species. - African Journal of Agricultural Research 7(32). DOI: 10.5897/AJAR12.214.

[21] Juhasz, C. C., leduc, A., Boyer, C., Guérin, F., Vernière, C., Pruvost, O., Wonni, I., Ouedraogo, L. (2013): First report of Xanthomonas citri pv. citri causing asiatic citrus canker in burkina faso. - Plant Disease 97: 1653-1653.

[22] Kalim, S., Luthra, Y. P., Gandhi, S. K. (2003): Cowpea root rot severity and metabolic changes in relation to manganese application. - Journal of Phytopathology 151: 92-97.

[23] Kjeldahl, J. (1983): Determination of protein nitrogen in food products. - Encyclopedia of Food and Agricultural Ethics 28: 757-759.

[24] Kumar, N., Ebel, R. C., Roberts, P. D. (2011): Antioxidant metabolism of grapefruit infected with Xanthomonas axonopodis pv. citri. - Environmental and Experimental Botany 71: 41-49. 
[25] Ladanyia, M., Ladaniya, M. (2010): Citrus Fruit: Biology, Technology and Evaluation. Academic Press, Amsterdam.

[26] Lakitan, B. (2007): Fundamentals of Plant Physiology. - Raja Grafindo Persada, Jakarta.

[27] Lee, H. A. (1918): Further data on the susceptibility of rutaceous plants to citrus-canker. - Journal of Agricultural Research 15: 661-665.

[28] Marschner, H. (1995): Mineral Nutrition of Higher Plants. $2^{\text {nd }}$ Ed. - Academic Press, Amsterdam.

[29] Memon, N. A. (2017): Citrus Fruit (Kino). Punjab Produced 98\% of Production. Pakistan Bureau of Statistics 2016-2017, Islamabad.

[30] Mubeen, M., Arshad, M. I. H., Iftikhar, H. M., Irfan, U. M., Bilqees, I. (2015): Biochemical charecterization of Xanthomon asaxonopodis pv. citri: a gram negative bacterium causing citrus canker. - International Journal of Science and Nature 6(2): 151154.

[31] Olanya, O., El-Bedewy, R., Ojiambo, P., Ewell, P., Hakiza, J. (2001): Relationships of Fungicide Application to Late Blight Development and Potato Growth Parameters in the Tropical Highlands of Uganda and Kenya. - International Potato Center 1990-2000, Lima, Peru.

[32] Pervaiz, S. (2015): Fruit, vegetable fail to enter European Union. A report. - http://the dailystar.net/business.

[33] Rice, R. W. (2007): The Physiological Role of Minerals in the Plant. - In: Datnoff, L. E. et al. (eds.) Mineral Nutrition and Plant Disease. American Phytopathological Society Press, St. Paul, MI, pp. 9-29.

[34] Roeschlin, R. A., Favaro, M. A., Chiesa, M. A., Alemano, S., Vojnov, A. A., Castagnaro, A. P., Filippone, M. P., Gmitter, F. G., Gadea, J., Marano, M. R. (2017): Resistance to citrus canker induced by a variant of Xanthomonas citri ssp. citri is associated with a hypersensitive cell death response involving autophagy-associated vacuolar processes. Molecular Plant Pathology18: 1267-1281.

[35] Ryan, R. P., Vorhölter, F.-J., Potnis, N., Jones, J. B., Van Sluys, M.-A., Bogdanove, A. J., Dow, J. M (2011): Pathogenomics of Xanthomonas: understanding bacterium-plant interactions. - Nature Reviews Microbiology 9: 344-355.

[36] Sahi, S. T., Ghazanfar, M. U., Afzal, M., Rashed, A., Habib, A. (2007): Incidence of citrus canker disease caused by Xanthomonas axonopodis pv. citri (Hasse) dows on Kinnow (Citrus reticulata) and its chemotherapy. - Pakistan Journal of Botany 39: 13-19.

[37] Sahi, S. T., Ghazanfar, M. U., Afzal, M., Wakil, W., Habib, A. (2010): Influence of inoculation with ascochyta lentis mineral contents $(\mathrm{Na}, \mathrm{Ca}, \mathrm{Mg}, \mathrm{Zn}, \mathrm{Cu}$ and $\mathrm{Fe}$ ) of susceptible and resistant lines of lentil (Lens culinaris medik.). - Pakistan Journal of Botany 42: 375-382.

[38] SAS Institute Inc. (2009): SAS Procedures Guide. Version 9.3. Third Edition. SAS Programming Tips: www.ats.ucla.edu/STAT/SAS/library/nesug00/bt3005. - SAS Institute Inc., Cary, NC.

[39] Schubert, T. S., Rizvi, S. A., Sun, X., Gottwald, T. R., Graham, J. H., Dixon, W. N. (2001): Meeting the challenge of eradicating citrus canker in Florida - again. - Plant Disease 85: 340-356.

[40] Spann, T. M., Schumann, A. W. (2010): Mineral Nutrition Contributes to Plant Disease and Pest Resistance. - University of Florida, IFAS Extension, Gainesville, FL.

[41] Spann, T., Schumann, A. (2012): Using good horticultural practices to maintain yield of HLB-affected groves. - Cell 772: 473-4142.

[42] Vandermeer, J., Perfecto, I., Philpott, S. (2010): Ecological complexity and pest control in organic coffee production: uncovering an autonomous ecosystem service. - BioScience 60: 527-537.

[43] Wali, S., Munir, F., Mahmood, T. (2013): Phylogenetic studies of selected citrus species based on chloroplast gene, rps14. - International Journal of Agricultural Biology 15: 357361. 
Hameed et al:: Progressive alterations in mineral profiling of citrus infected with canker caused by Xanthomonas axonopodis pv. citri (Hasse)

- 13642 -

[44] Ware, M. (2015): Oranges: health benefits, nutritional information. https://www.medicalnewstoday.com/articles/272782.php.

[45] Zekri, M., Obreza, T. (2015): Macronutrient Deficiencies in Citrus: Nitrogen. Phosphorus, and Potassium. - University of Florida. IFAS Extension, Gainesville, FL. http://edis. ifas.ufl.edu/ss420. 